\title{
Community Resilience of Jeruksawit Village in Facing Covid-19 Pandemic in 2020 (Case Study in Jeruksawit Village, Gondangrejo Subdistrict, Karanganyar Regency)
}

\author{
Rita Mawanti Kusuma Nurbersari, Yasin Yusup, Rita Noviani \\ Universitas Sebelas Maret Surakarta \\ ritamawanti.rm@gmail.com
}

Article History

accepted 31/08/2020

approved 22/09/2020

published 28/10/2020

\begin{abstract}
ion
Coronavirus Disease-2019 (COVID-19) is an infectious disease caused by Severe Acute Respiratory Syndrome Coronavirus 2 (SARS-COV2). In Indonesia the virus is spreading rapidly from urban to the rural areas. The aim of this study: 1) Determine the distribution moment COVID-19 in the village of Jeruksawit and, 2) Determine the level of resilience of the village community in Jeruksawit terms of health, physical, social, economic, and spatial planning in the face of the COVID-19 pandemic. The used of data source was the result of interviews with officials government and residents of Jeruksawit Village. Observation of village spatial planning as primary data, secondary data from Jeruksawit Village monographs. Data analysis use scoring method based on several indicators using a Likert scale. The results of the research showed that the spread of Covid-19 in Jeruksawit Village was 0 cases. Jeruksawit Village has high resilience to COVID-19 and can doing activities as usual smoothly.
\end{abstract}

Keywords: Covid -19, Pandemic, Resilience

\begin{abstract}
Abstraksi
Coronavirus Disease-2019 (COVID-19) adalah penyakit menular yang disebabkan oleh Severe Acute Respiratory Syndrome Coronavirus 2 (SARS-COV2). Di Indonesia virus ini menyebar dengan cepat dari perkotaan hingga ke pedesaan. Penelitian ini bertujuan 1) Mengetahui momen distribusi COVID-19 di Desa Jeruksawit dan, 2) Mengetahui tingkat resiliensi masyarakat Desa Jeruksawit ditinjau dari kesehatan, fisik, sosial, ekonomi, dan tata ruang dalam menghadapi pandemi COVID-19. Sumber data yang digunakan adalah hasil wawancara dengan aparat pemerintahan dan warga Desa Jeruksawit. Observasi tata ruang desa sebagai data primer, data sekunder dari monografi Desa Jeruksawit. Analisis data menggunakan metode skoring berdasar beberapa indikator dengan menggunakan skala Likert. Hasil penelitian menunjukkan penyebaran Covid-19 Desa Jeruksawit 0 kasus. Desa Jeruksawit memiliki resiliensi tinggi terhadap COVID-19 dan bisa beraktifitas seperti biasa dengan lancar Kata kunci: Covid-19, Pandemi, Resiliensi
\end{abstract}

Social, Humanities, and Education Studies (SHEs): Conference Series https://jurnal.uns.ac.id/shes

p-ISSN 2620-9284 e-ISSN 2620-9292 


\section{PENDAHULUAN}

Coronavirus Disease-2019 (COVID-19) adalah penyakit menular yang disebabkan oleh Severe Acute Respiratory Syndrome Coronavirus 2 (SARS-COV2), ditemukan pada manusia sejak kejadian luar biasa muncul di Wuhan Cina, Desember 2019. Penyebab penyakit ini sama dengan penyebab SARS tahun 2003, hanya berbeda jenis virusnya. COVID-19 memiliki penyebaran yang lebih luas dan cepat ke beberapa negara dibanding SARS (WHO, 2019).

Semua orang dapat terserang COVID-19, orang berusia lanjut, dan yang memiliki masalah medis mendasar seperti penyakit kardiovaskular, diabetes, penyakit pernapasan kronis, dan kanker rentan untuk terpapar penyakit serius. Virus COVID-19 menyebar terutama melalui tetesan air liur/ keluar dari hidung ketika orang yang terinfeksi batuk/ bersin (WHO, 2020). Sumber utama infeksi adalah pasien COVID-19 dan pembawa (carrier) COVID-19 tanpa gejala. Rute penularan utama adalah droplets pernapasan dan kontak dekat, sementara rute penularan aerosol dan fecal-oral belum diverifikasi.

Di Indonesia, penyebaran COVID-19 terjadi melalui serangkaian momen yang bersifat dinamis, mulai dari masyarakat yang mengabaikan virus karena Indonesia 0 kasus dan masyarakat merasa "kebal" terhadap COVID-19. Hingga secara resmi diumumkan Presiden Joko Widodo ada dua WNI dinyatakan positif COVID-19, yaitu perempuan berusia 31 tahun dan 64 tahun melalui media massa, pada 2 Maret 2020.

Seiring waktu, jumlah orang terinfeksi semakin bertambah karena tingginya kecepatan penyebaran virus corona. Setiap kasus terinfeksi bisa menularkan 2-3 orang lainnya. Double time rata-rata 5/hari, 10 jadi 20, 40, dan seterusnya. Melihat kecepatan penyebaran COVID-19 di banyak negara, pada 11 Maret 2020, WHO menyatakan COVID-19 sebagai Global Pandemic.

Di Indonesia, jumlah penderita COVID-19 semakin bertambah, 31 Maret 2020, Pemerintah Indonesia mengeluarkan PP Nomor 21 Tahun 2020 tentang Pembatasan Sosial Berskala Besar (PSBB), dan berdasarkan Keputusan Presiden Nomor 12 Tahun 2020 tentang Bencana Non-Alam, COVID-19 dinyatakan sebagai Nasional Disaster. Sebagaimana dilakukan oleh berbagai negara terdampak, Pemerintah Indonesia mengambil tindakan mengurangi penyebaran melalui physical distancing, anjuran memakai masker dan rajin mencuci tangan, beribadah dari rumah, bekerja dari rumah, kegiatan belajar-mengajar dari berbagai tingkatan dari rumah, pembatasan jumlah moda transportasi yang beroperasi, pembatasan perjalanan ke luar negeri, hingga kebijakan lockdown.

Sebagai bencana nasional, pandemik COVID-19 berdampak pada seluruh wilayah di Indonesia. Tak terkecuali Desa Jeruksawit, Kecamatan Gondangrejo, Kabupaten Karanganyar, Jawa Tengah. Hingga saat ini, tidak ada catatan medis yang menyatakan adanya pasien positif COVID-19 di Desa Jeruksawit tetapi masyarakat Desa Jeruksawit turut merasakan dampak tak langsung akibat COVID-19. Hal ini dipengaruhi oleh beragam faktor, terutama masyarakat di wilayah bersangkutan. Momen ini menggambarkan siklus adaptif masyarakat Desa Jeruksawit dalam menghadapi COVID-19, terbagi dalam beberapa tahapan sebagaimana proses Teori Panarchy. Penting diketahui, desa terdampak, maupun tidak terdampak masyarakatnya diharapkan memiliki tingkat resiliensi (Holling, 1973) menghadapi pandemi COVID-19, terutama dalam menyongsong New Normal Era.

Kang et al. (2007) mendefinisikan resiliensi sebagai kemampuan sistem untuk pulih setelah bahaya terjadi dan mengukur resiliensi berdasarkan durasi kondisi yang tidak memuaskan. Keye \& Pidgeon (2013) mendefinisikan resiliensi sebagai kemampuan untuk "mempertahankan stabilitas psikologis dalam menghadapi stres".(Rojas F., 2015) menyatakan resiliensi sebagai kemampuan menghadapi tantangan, tampak ketika seseorang menghadapi pengalaman yang sulit dan tahu bagaimana menghadapi atau beradaptasi dengannya (Utami, 2017). 
Buzz Holling dan koleganya mengeluarkan buku yang merangkum perkembangan pemikiran tentang resiliensi di berbagai bidang keilmuan dengan judul Panarchy (Gunderson \& Holling, 2002). Terdapat tiga postulat yang ditawarkan yaitu; siklus adaptif, panarchy, domain kestabilan. Dalam kerangka sistem sosial-ekologis, resiliensi masyarakat tercermin dalam siklus adaptif empat tahap, setiap tahap memiliki laju dan proses yang berbeda, yaitu: tahap Pertumbuhan $(r)$ di mana pertumbuhan terjadi sangat cepat, ditandai dengan akumulasi sumber daya yang cepat, persaingan, perebutan peluang, meningkatnya tingkat keanekaragaman dan koneksi, ketahanan yang tinggi. Tahap Konservasi $(\mathrm{K})$ ditandai dengan pertumbuhan melambat karena sumber daya disimpan dan digunakan sebagian besar untuk pemeliharaan sistem. Fase ini ditandai oleh: stabilitas, kepastian, fleksibilitas berkurang, ketahanan rendah. Tahap Pelepasan $(\Omega)$ terjadi ketika sistem telah runtuh, dapat kembali mengumpulkan sumberdaya yang dilepasnya untuk tumbuh menjadi sistem dengan identitas sama, atau menjadi sistem baru yang sama sekali berbeda, menciptakan siklus tidak terputus. Tahap Reorganisasi ( $\alpha$ ) adalah masa inovasi, membatasi ketidakpastian terbesar tetapi dengan ketahanan tinggi.

Pan-archy dari bahasa Latin; Pan/Faun adalah Dewa yang menguasai alam dan hewan-hewan, serta archy yang berarti pengaturan. Dalam konsep panarchy, sistem ekologi-sosial memiliki proses pengaturan mandiri lintas skala, setiap tingkatan memiliki dinamika berbeda. Panarchy berbeda dengan hierarki yang menggambarkan kekakuan dalam hubungan lintas skala. Sistem di alam dan masyarakat terdiri atas tingkatan. Setiap tingkatan memiliki siklus adaptif dengan laju, proses dan variabel kunci yang berbeda. Meskipun demikian, sistem tersebut memiliki keterkaitan satu sama lain (Gambar 1b). Siklus adaptif mempengaruhi laju dan proses siklus adaptif di sistem di atas/bawahnya. Sistem yang kecil memiliki laju siklus lebih cepat, sebaliknya pada sistem yang besar, sistem yang lebih kecil mempercepat siklus adaptif di atasnya dan berperan sebagai gangguan, sistem yang lebih besar memperlambat dan berperan sebagai domain kestabilan. Hubungan lintas skala ini diistilahkan sebagai Panarchy (Holling dkk, 2002; Berkes \&Folke, 2002)

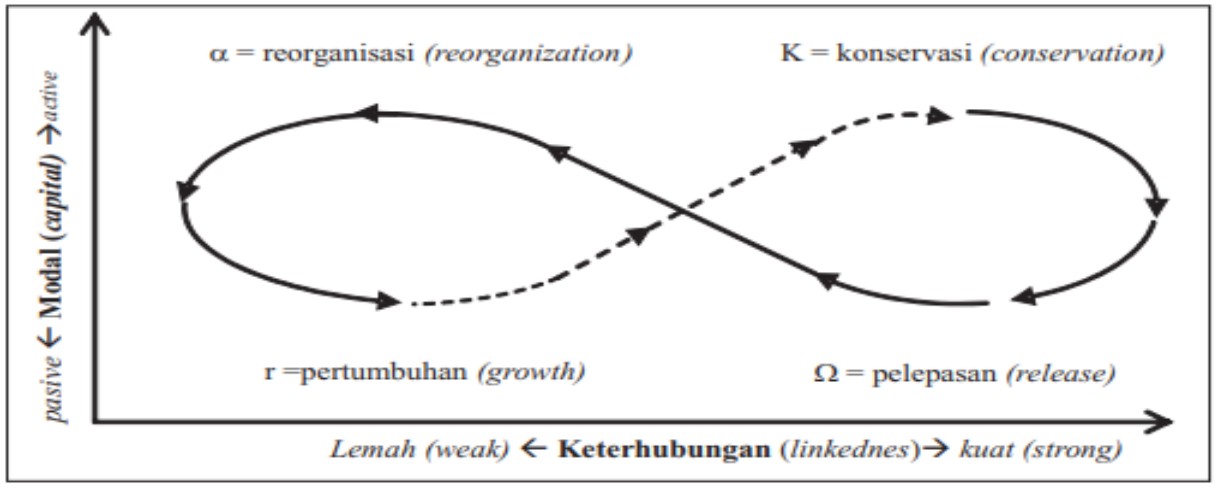

Gambar 2. Siklus Adaptif Empat Fungsi (Diadaptasi dari Holling et al., 2000)

Sebagaimana disebutkan, sistem yang lebih besar berperan sebagai domain kestabilan bagi sistem yang lebih kecil. Apabila dianalogikan sebagai bola di dalam cawan, maka domain kestabilan adalah cawan tersebut. Sistem menempati satu kondisi kestabilan, seiring dengan dinamika domain kestabilannya, maka sistem dapat berpindah ke kondisi kestabilan yang lain. Resiliensi dilihat sebagai kondisi dimana sistem masih berada dalam domain kestabilan tertentu dan tidak bergeser ke domain kestabilan yang baru. Resiliensi dari suatu sistem bergantung pada seberapa dalam cawan yang ditempatinya (indikasinya seberapa sulit menggeser sistem ke kondisi stabil yang baru), seberapa besar domain kestabilan yang ada, dan posisi sistem relatif terhadap tepian cawan. Domain kestabilan tidaklah statis, tetapi berubah karena 
pengaruh domain kestabilan yang lain,sehingga menentukan resiliensi dari sistem yang ada.

Untuk mengetahui tingkat resiliensi masyarakat Desa Jeruksawit dalam menghadapi pandemi COVID-19, perlu diketahui bagaimana kondisi kesehatan, kondisi fisik wilayah, kondisi sosial dan ekonomi, kondisi tata ruang, serta kebijakan yang ditetapkan oleh aparat Desa Jeruksawit. Kondisi tersebut diketahui melalui serangkaian indikator yang diakumulasikan untuk mengetahui masyarakat Desa Jeruksawit termasuk resiliensi yang rendah, sedang, atau tinggi. Dari uraian tersebut tujuan penelitian ini adalah: 1) Mengetahui momen distribusi COVID-19 di Desa Jeruksawit, 2) Mengetahui tingkat resiliensi masyarakat Desa Jeruksawit ditinjau dari segi kesehatan, fisik, sosial, ekonomi, dan tata ruang dalam menghadapi pandemi COVID-19.

Penelitian ini dilaksanakan di Desa Jeruksawit, Kecamatan Gondangrejo, Kabupaten Karanganyar. Data yang digunakan dalam penelitian ini yaitu; data kependudukan/demografis masyarakat Desa Jeruksawit, data kondisi kesehatan, data kondisi pertanian, data kondisi peternakan dengan sumber datanya yaitu Kecamatan Gondangrejo Dalam Angka 2019. Pengumpulan data dilakukan dengan wawancara, dokumentasi dan observasi lapangan untuk memperoleh data momen penyebaran COVID-19 di Desa Jeruksawit, kondisi fisik Desa Jeruksawit, dan kondisi tata ruang Desa Jeruksawit.

Analisa data dilakukan dengan analisis interaktif model milles dan huberman serta skoring untuk menentukan tingkat resiliensi penduduk dalam menghadapi pandemi Covid-19 menggunakan analisis faktor-faktor yang mempengaruhi resiliensi berdasarkan tabulasi data dengan modifikasi peneliti terkait pandemi COVID-19. Data direduksi berdasar tahapan 4 siklus adaptif, berikutnya disajikan diagram siklus adaptif dengan konsep Panarchy dan terakhir penarikan kesimpulan. Skala Resiliensi dihitung dengan menggunakan skala Likert. Skor total tertinggi merupakan desa dengan tingkat resiliensi tinggi dan jumlah skor terendah merupakan desa dengan tingkat resiliensi rendah. Faktor yang digunakan untuk menghitung skoring adalah kesehatan, ekonomi, fisik, sosial, tata ruang dan kebijakan yang dilakukan pemerintah desa. Kesimpulan berdasarkan reduksi dan penyajian data. Penarikan kesimpulan berlangsung bertahap, dari kesimpulan umum pada tahap reduksi data, kemudian menjadi lebih spesifik pada tahap penyajian data, dan lebih spesifik lagi pada tahap penarikan kesimpulan sebenarnya.

\section{HASIL DAN PEMBAHASAN \\ 1. Momen Persebaran Covid-19 di Desa Jeruksawit}

Desa Jeruksawit secara administratif berada di Kecamatan Gondangrejo Kabupaten Karanganyar. Sebelah selatan berbatasan dengan Desa Plesungan dan Desa Wonorejo, sebelah barat dengan Desa Jatikuwung, utara dengan Desa Wonosari dan timur dengan Desa Kragan. Pada masa pandemi COVID19 Kabupaten Karanganyar merupakan daerah zona hijau. Hal ini diakibatkan oleh adanya 0 kasus COVID-19. Desa Jeruksawit sebagai bagian dari Kabupaten Karanganyar juga mengalami 0 kasus COVID-19. Dari hasil wawancara diketahui bahwa di Desa Jeruksawit tidak terjadi kasus COVID-19 karena penduduk telah melakukan protokol kesehatan yang dianjurkan sebelum terjadi pandemi COVID-19. Penduduk desa yang pergi merantau ke luar daerah tidak diperkenankan untuk pulang oleh keluarga masing-masing.

Aparat pemerintah desa bersama masyarakat bahu-membahu dalam melaksanakan protokol kesehatan. Adanya sinergi antara aparat pemerintah desa, petugas kesehatan dan penduduk desa menjadikan Desa Jeruksawit 
selama pandemi selalu 0 (nol) kasus COVID-19, dan bisa dikatakan tidak terlalu terpengaruh oleh dampak pandemi COVID-19.

\section{Resiliensi Masyarakat Desa Jeruksawit.}

Secara struktural rumah penduduk berhimpitan satu sama lain, memanjang mengikuti jalan sebagai imbas pembangunan Tol Solo Kertosono dan jalur lintas Solo-Sragen. Tiap rumah memiliki halaman sebagai tempat berinteraksi, menjemur hasil panen dan menanam sayuran. Rumah penduduk memiliki dua pintu, satu pintu utama menuju ruang tamu dan satunya adalah pintu yang mengarah ke bagian belakang rumah dan kandang. Hal ini dibuat dengan tujuan setelah dari sawah ataupun bepergian akan langsung mandi baru masuk rumah. Di halaman terdapat keran air yang memudahkan setiap orang untuk mencuci tangan. Kebiasaan mencuci tangan dan bersih diri setelah kegiatan ataupun sebelum masuk rumah sudah menjadi pembiasaan yang mendarah daging sejak dulu. Bangunan rumah didominasi oleh tembok dan sangat jarang ditemukan rumah berdinding gedeg maupun kayu.

Desa Jeruksawit merupakan desa yang berpenduduk padat. Hal ini disebabkan munculnya klaster perumahan sebagai dampak pelebaran pengembangan Kota Surakarta ke arah utara. Kepadatan penduduknya 956 orang per $\mathrm{Km}$ dengan distribusi penduduk 6,7\%. Pernikahan dini masih kerap terjadi sehingga tingkat pertumbuhan penduduknya cenderung tinggi. Jumlah penduduk usia non produktif (0-14 tahun dan >64 tahun) sebanyak 1632 orang $(30,48 \%)$.

Sekolah masih dilakukan secara daring online terutama siswa SMP SMA/K. Guru TK dan SD akan mendatangi rumah siswa, pembelajaran secara kelompok untuk setiap pertemuan .Penduduk Desa Jeruksawit 5273 orang beragama Islam dan 16 orang beragama protestan. Jumlah masjid sebanyak 14 buah dan 3 buah mushola, sedangkan gereja tidak terdapat di Desa Jeruksawit. Sesuai protokol kesehatan maka sholat berjamaah ditiadakan, akan tetapi di Desa Jeruksawit sebagian tetap dilaksanakan sholat berjamaah. Jamaah terbatas pada lingkup lingkungan sekitar. Kegiatan sosial pemuda, PKK dan kumpulan bapak-bapak dihentikan hingga awal bulan juli. Posyandu dihentikan, pemeriksaan balita dan lansia langsung ke bidan desa, klinik ataupun rumah sakit.

Desa Jeruksawit terdapat satu akses angkot trayek $11 \mathrm{~A}$, beroperasi mulai jam 4 pagi hingga 5 sore dengan jeda setiap 1 jam sekali. Angkot hanya dinaiki yang sudah langganan setiap harinya. Setiap keluarga rata-rata memiliki 2 motor sebagai alat transportasi.Komunikasi antar penduduk terjadi lewat tatap muka secara langsung setiap hari. Saling sapa saat lewat ataupun saat berkumpul di sawah dan tegal. Terdapat pula komunikasi melalui chat online sebagai komunikasi untuk menyampaikan info-info terbaru dari pemerintah untuk warga. Dari segi keamanan ronda malam berlangsung setiap hari setiap malam dengan bergiliran jadwal. Pos ronda dibangun pojok desa di semua dukuh.

Desa Jeruksawit merupakan desa agraris, warga desa bermata pencaharian utama sebagai petani. Bertani dilakukan pagi dan sore hari, siang sebagai anak kandang dan buruh bangunan. Wanita memegang peran penting karena selain sebagai ibu rumah tangga juga mempertahankan ekonomi keluarga dengan membuat kreneng bambu. Menurut tingkat kesejahteraannya maka desa Jeruksawit termasuk banyak yang belum sejahtera. Distribusi keluarga sejahtera dan pra sejahtera bisa dilihat dalam tabel berikut; 
SHEs: Conference Series 3 (1) (2020) 238- 244

Tabel 1. Banyaknya keluarga menurut kesejahteraan

\begin{tabular}{lll}
\hline No & Tingkat kesejahteraan & jumlah \\
\hline 1 & Pra KS & 616 \\
2 & KS I & 290 \\
3 & KS II & 426 \\
4 & KS III & 470 \\
5 & KS III+ & 48 \\
\hline & JUMLAH & 1850 \\
\hline
\end{tabular}

Tingkat pendidikan warga desa umumnya rendah. Minimal pendidikan yang ditempuh warga desa hanya sampai SMP/MI bahkan seringkali karena keterbatasan ekonomi ada yang putus sekolah saat masih SD/MI. Adanya tingkat pendidikan rendah maka pekerjaan yang dilakukan hanya yang mengandalkan tenaga ataupun ketrampilan dengan penghasilan kecil. Dengan adaya pendidikan yang terbatas, maka warga desa memanfaatkan apa yang ada di sekitarnya secara detail, halaman rumah ditanami dengan sayuran sehingga meminimalisir pengeluaran. Setiap panen dibelikan perhiasan emas sebagai cadangan hidup disaat sulit. Saat pandemi COVID-19 Desa Jeruksawit baru saja usai panen sehingga tidak terjadi dampak yang besar terhadap perekonomian karena cadangan beras masih banyak dan warga desa yang bekerja sebagai kuli bangunan mendapat pekerjaan membuat kluster perumahan baru.

Kebijakan yang diambil pemerintah dalam kondisi covid ini sangat banyak diantaranya ada (a) sosial distancing, Warga menaati nya dengan cara PKK atau pun bapak-bapak selama pandemi ini tidak diperkenankan untuk mengadakan pertemuan, tidak mengadakan hajatan. Bagi warga yang beribadah ke mesjid harus dengan protokoler covid yaitu jaga jarak dan memakai masker (b) Pemberian bantuan,warga menerima bantuan langsung tunai dari pemerintah. Warga yang kurang akan meneriima bantuan pangan dari warga lain yang berlebih (c) PHBS dengan cara melakukan sterilisasi tempat umum dengan penyemprotan desinfektan secara berkala, menyediaan hand sanitizer di tempat umum, seperti masjid dan pos ronda, membagi masker untuk warga.

\section{KESIMPULAN}

1. Berdasarkan hasil penelitian yang telah dilakukan, tidak terjadi momen persebaran COVID 19 Desa JerukSawit.

2. Resiliensi di Desa Jeruksawit tinggi karena berdasarkan parameter kesehatan, ekonomi, fisik, sosial, tata ruang dan kebijakan yang dilakukan pemerintah desa sangat memenuhi syarat ketahanan. Masyarakat tetap beraktivitas seperti biasa dengan memperhatikan himbauan dan aturan yang telah diterapkan oleh pemerintah. Semua dukuh berada pada kondisi yang sama, melaksanakan indikator yang digunakan untuk resiliensi secara aktif bahkan dari sebelum menjadi himbauan dari pemerintah. Tidak terjadi perubahan secara ekonomi dan sosial sebagai akibat dari tingkat pendidikan rendah, pekerjaan seragam ( petani dan kuli bangunan) dan kemampuan masyarakat untuk mempertahankan diri dengan memanfaatkan lingkungan sekitar. 


\section{DAFTAR PUSTAKA}

Holling, C. S. (1973). Resilience and Stability of Ecological Systems. Annu.Rev.Ecol.Syst., 4, 1-23. doi:10.1146/annurev.es.04.110173.000245

Holling, C.S. \& Gunderson, L.H. (2002). Resilience and Adaptive Cycles. In L.H. Gunderson \& C.S. Holling (Eds.). Panarchy: Understanding Transformations in Human and Natural Systems. Washington: IslandPress

Kang B, Lee SJ, Kang DH, Kim YO (2007) A flood risk projection for Yongdam dam against future climate change. J Hydro-Environ Res 1(2):118-125. doi:10.1016/j.jher.2007.07.003

Kecamatan Gondangrejo Dalam Angka 2019.(2019).BPS Kabupaten Karanganyar

Keye, M. D., \& Pidgeon, A. M. (2013). Investigation of the Relationship between Resilience, Mindfulness, and Academic Self-Efficacy. Open Journal of Social Sciences, 01(06), 1-4. https://doi.org/10.4236/jss.2013.16001

Letko et al. (2020). Functional assessment of cell entry and receptor usage for SARSCoV-2 and other lineage B betacoronaviruses. Nature Microbiology: 1-8. doi:10.1038/s41564-020-0688-y

PP Nomor 21 Tahun 2020 tentang Pembatasan Sosial Berskala Besar

Safrizal, dkk. (2020). Pedoman Umum Menghadapi Pandemi COVID-19 Bagi Pemerintah Daerah. Tim Krja Kementrian Dalam Negeri Untuk Dukungan Gugus Tugas COVID-19.

Utami, C. T. (2017). Self-Efficacy dan Resiliensi: Sebuah Tinjauan Meta-Analisis.

Buletin Psikologi, 25(1), 54-65. https://doi.org/10.22146/buletinpsikologi.18419 